\title{
The genus Paguristes (Crustacea: Decapoda: Diogenidae) from Cuba (Western Atlantic). A new record and a new species*
}

\author{
MARÍA EUGENIA MANJÓN-CABEZA ${ }^{1}$, JOSÉ ENRIQUE GARCÍA RASO ${ }^{1}$ and \\ JUAN CARLOS MARTÍNEZ IGLESIAS ${ }^{2}$ \\ ${ }^{1}$ Departamento de Biología Animal. Facultad de Ciencias. Universidad de Málaga. Campus de Teatinos s/n. \\ 29071 Málaga. Spain. E-mail: garciaraso@uma.es \\ ${ }^{2}$ Instituto de Oceanología de Cuba. Ministerio de Tecnología, Ciencia y Medio Ambiente. La Habana. Cuba.
}

\begin{abstract}
SUMMARY: The present paper presents an overview of the studies on the genus Paguristes from the Caribbean Sea and more specifically from Cuban waters. Additionally, the hermit crabs belonging to the genus Paguristes collected during different surveys of the "Instituto de Oceanología de Cuba" on the Cuban coast have been listed. A new species of hermit crab, Paguristes hologuinensis sp. nov., is described and remarks on a new record, Paguristes paraguanensis MacLaughlin and Provenzano, 1974, are given.
\end{abstract}

Key words: taxonomy, Paguristes, Caribbean Sea, Cuba.

\section{INTRODUCTION}

The genus Paguristes Dana, 1852, is the largest genus of the family Diogenidae distributed in shallow waters of all tropical and subtropical areas and is well represented in the West Indian region. The study of this genus started with Dana (1852) describing the species collected in the United States Exploring Expedition, from 1838 to 1842 . At the end of 19th century there were some authors who worked on this genus, such as Stimpson (1859), A. Milne Edwards (1880), A. Milne Edwards and Bouvier (1893), Benedict (1901), Bouvier (1918) and Schmitt $(1933,1935)$. Since the 1950s, these studies have not been stopped and many species have been described by Forest (1954), Wass (1955, 1963),

\footnotetext{
*Received April 10, 2001. Accepted October 17, 2001.
}

Holthuis (1959), Provenzano (1959, 1962, 1965), Forest and Saint Laurent (1967), MacLaughlin and Provenzano (1974 a,b), Martínez-Iglesias and Gómez-Hernández (1989), Campos and Sánchez (1995), and Sandberg (1996).

MacLaughlin and Provenzano (1974 a) reported on seven species of the Paguristes tortugae Schmitt, 1933 complex, four of which were described as new species. That paper constituted the first part of a continuing series of reports on regional Paguristes species. At that time, the authors knew of the existence of at least three additional species complexes. In the second part of the series (MacLaughlin and Provenzano, 1974 b), they described six new species of Paguristes, but none of these were associated with the three previously recognized complexes.

Within this genus there are a number of problematic species, probably because morphological 
variations are frequent and because some species were poorly described, which makes the identifications difficult and reveals a limited or imperfect knowledge of the group.

The decapods along the Caribbean coast of Cuba have been poorly studied. Most works include hermit crab records. Parra (1787) made the first studies about Cuban pagurids. Other studies were made by: Guérin-Meneville (1856) (in Gómez Hernández and Pérez 1984), Martens (1872), Gundlach and Torralbas (1896) (in Gómez Hernández and Pérez 1984), Valdés (1909), Torralbas (1917), Boone (1930), Schmitt (1935), Chace (1939), Provenzano (1959, 1960), Williams (1965), MacLaughlin and Provenzano (1974a), Ortiz (1976), Lalana et al. (1980), Rodríguez (1980), Gómez Hernández and Pérez (1984, 1987), Ortiz and Gómez Hernández (1986), Gómez Hernández and Martínez-Iglesias (1986), Martínez-Iglesias and Gómez Hernández (1989), Martínez-Iglesias et al. (1993) and Martínez-Iglesias and García Raso (1999).

The aim of the present study is to increase the knowledge of the genus Paguristes in the Caribbean Sea and specifically on the Cuban coast.

\section{MATERIAL AND METHODS}

The material studied was collected during different surveys of the "Instituto de Oceanología de Cuba" in 1987 and 1988 in shallow waters (2-10 m depth), by a benthic sucker air machine and by hand. The sampling areas, located in the North and South of Cuba, were: Medano la Vela in the North Keys of Sabana-Camagüey Islands (Fig. 1A); Vita Bay and Jururú Bay in Província de Holguin, N.E. Cuba (Fig. 1C), and in the Juan García Reef, Cantiles Reef and Diego Pérez Reef in Batabanó Gulf (Fig. 1B).

\section{RESULTS}

With the new record and species mentioned in this paper a total of 12 species of Paguristes have been reported in Cuban waters, however it is a relative low number taken into account that 35 species have been caught in the Caribbean Sea (Table 1).

Material analyzed, from Cuban littoral shallow waters, in this study:

Paguristes cadenati Forest, 1954: Medano la
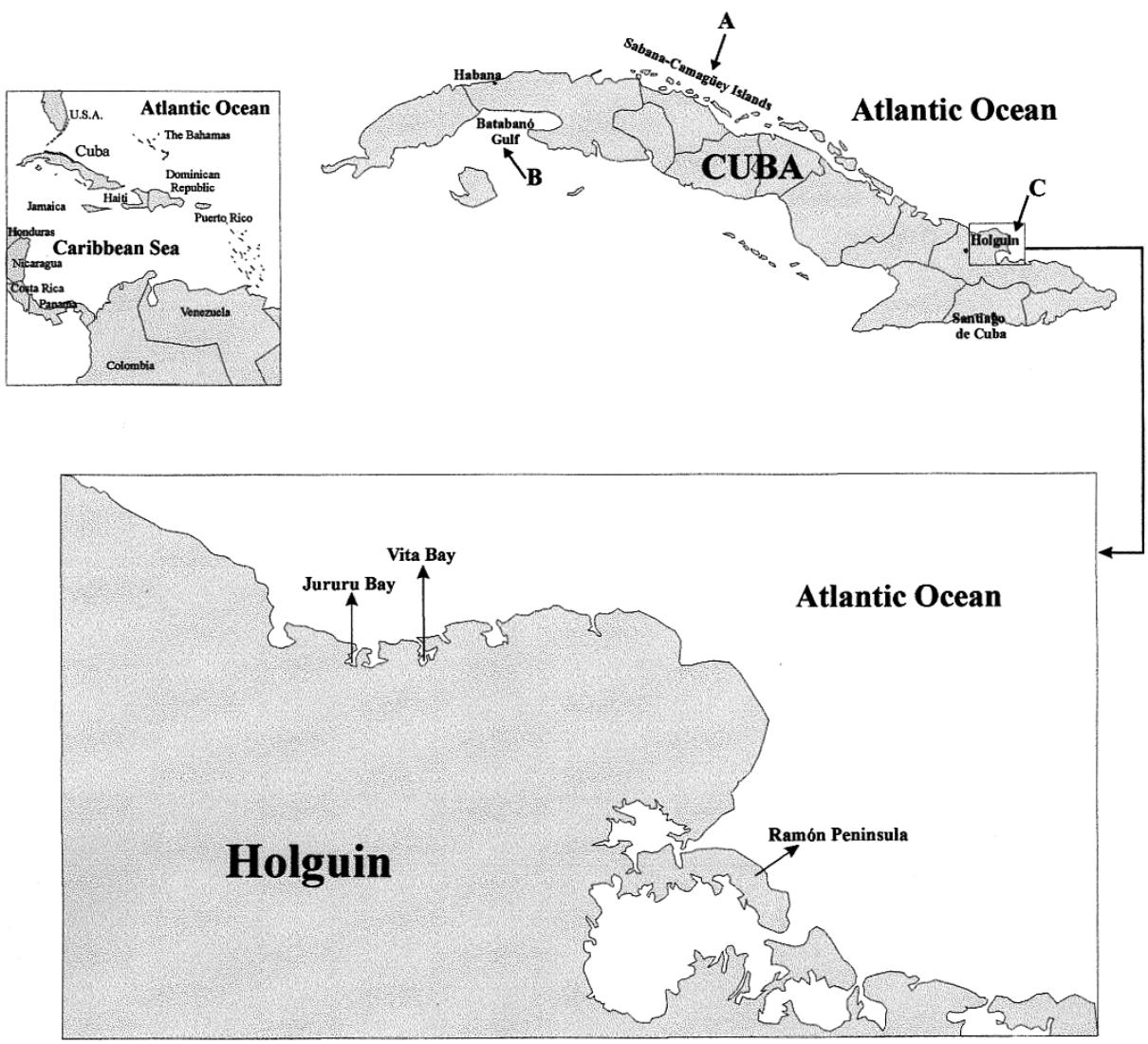

FIG. 1. - Location of the study areas in Cuba. 
TABLE 1. - Check list of the Caribbean Sea species. In the right column the first references for Cuban waters are indicated. The species observed in this study are marked with (+). [Notes: Paguristes rectifroms Benedict, 1901 and Paguristes teunirostris Benedict, 1901, have been considered synonyms of Paguristes sericeus according to Williams (1984), based on Provenzano and Rice (1966). On the other hand, Paguristes taeniatus mentioned in Benedict (1901) is a Clibanarius (R. Lemaitre, pers. comm.)].

P. anaryballus Provenzano, 1965.

P. angustitheca McLaughlin and Provenzano, 1974.

$P$. anomalus Bouvier, 1918.

P. cadenati Forest, 1954.

P. depressus Stimpson, 1859

P. erythrops Holthuis, 1959.

$P$. grayi Benedict, 1901 .

$P$. hernancortezi MacLaughlin and Provenzano, 1974.

P. hewatti Wass, 1963.

$P$. holguinensis sp. nov.

P. hummi Wass, 1955.

P. inconstans MacLaughlin and Provenzano, 1974.

P. invisisacculus MacLaughlin and Provenzano, 1974.

P. lapillatus MacLaughlin and Provenzano, 1974.

P. laticlavus MacLaughlin and Provenzano, 1974.

P. limonensis MacLaughlin and Provenzano, 1974.

P. lymani A. Milne Edwards and Bouvier, 1893.

P. maclaughlinae Martínez-Iglesias and Gómez, 1989.

P. markhami Sandberg, 1996

P. moorei Benedict, 1901.

P. oxyophthalmus Holthuis, 1959.

P. paraguanensis MacLaughlin and Provenzano, 1974.

$P$. perplexus MacLaughlin and Provenzano, 1974.

P. planatus A. Milne Edwards and Bouvier 1893.

$P$. puncticeps Benedict, 1901.

$P$. sayi A. Milne Edwards and Bouvier, 1893.

$P$. sericeus A. Milne Edward, 1880.

P. spectabilis MacLaughlin and Provenzano, 1974.

$P$. spinipes A. Milne Edwards, 1880.

P. starcki Provenzano, 1965.

P. tortugae Schmitt, 1933.

P. triangulatus A. Milne Edwards and Bouvier, 1893.

P. wassi Provenzano, 1961.

$P$. werdingi Campos and Sánchez, 1995.

P. zebra Campos and Sánchez, 1995.

\author{
Bouvier (1918) (+) \\ Martínez-Iglesias et al. (1993) (+) \\ Gómez and Pérez (1984) \\ Martínez-Iglesias et al. (1993) (+) \\ Lalana et al. (1980) (+)
}

(+) New species

Gómez and Martínez-Iglesias (1986)

Martínez-Iglesias and Gómez (1989)

(+) New record

Martínez-Iglesias et al. (1993) (+)

Goundlach and Torralbas (1896) (+)

Gómez and Martínez-Iglesias (1986)
Vela: (MV-2) 1 ๙ิ.

Paguristes anomalus Bouvier, 1918 : Batabanó Gulf?: (77-4) 1 ㅇ.

Paguristes perplexus McLaughlin and Provenzano, 1974: Juan García Reef: (AJG-8) 10 .

Paguristes puncticeps Benedict, 1901: Juan García Reef: (AJG-13) 1 . .

Paguristes paraguanenesis McLaughlin and Provenzano, 1974: Juan García Reef: (126-14) 10 .

Paguristes erythrops Holthuis, 1959: Diego Pérez Reef: (ADP-16) 1 \% ; Batabanó Gulf: (\#6-24) 1 9 ; Cuba but without specific locality: (SE28:1) ô; Diego Pérez Reef: (ADP-25): 2 ㅇ.

Paguristes grayi Benedict, 1901: Diego Pérez Reef: (ADP-17) 1 o and (ADP-21) 10; Cuba but without specific locality: (SE-22) 1 juv.; Batabanó Gulf?: (21-23) 1 ㅇ․

Paguristes holguinensis sp. nov.:Vita Bay: (2VA9) 10 , (2VA-6) 1 , , (2VA-12) $19,(2 \mathrm{VA}-26) 1 \%$, (26VA-5) $1+$ and 1 $\hat{\sigma},(2 \mathrm{VA}-15) 10$, Jururú Bay: (6JA-10) $1 \hat{\sigma},(10 \mathrm{JA}-11) 1 \hat{\sigma}$.
Paguristes paraguanensis McLaughlin and Provenzano, 1974.

Material examined: Juán García Reef, Batábano Gulf, SW Cuba, 13-1988: (126-14) 1 ô.

Remarks: P. paraguanensis is recorded for the first time in Cuban waters. This species could be confused with P. erythrops; both species are present in Cuba and they are sympatric in the coral reefs in Batabanó Gulf. The main character which can help to distinguish $P$. paraguanensis and $P$. erythrops from most other species of Paguristes is the presence of spines on the fifth segments of the antennal peduncles (MacLaughlin and Provenzano, 1974b). On the other hand, the most reliable morphological characters to differentiate these species from each other are: (1) the presence of a prominent spine at the dorsodistal margin of the carpus of the fourth pereiopod, which is present in $P$. erythrops and absent in $P$. paraguanensis (McLaughlin and 

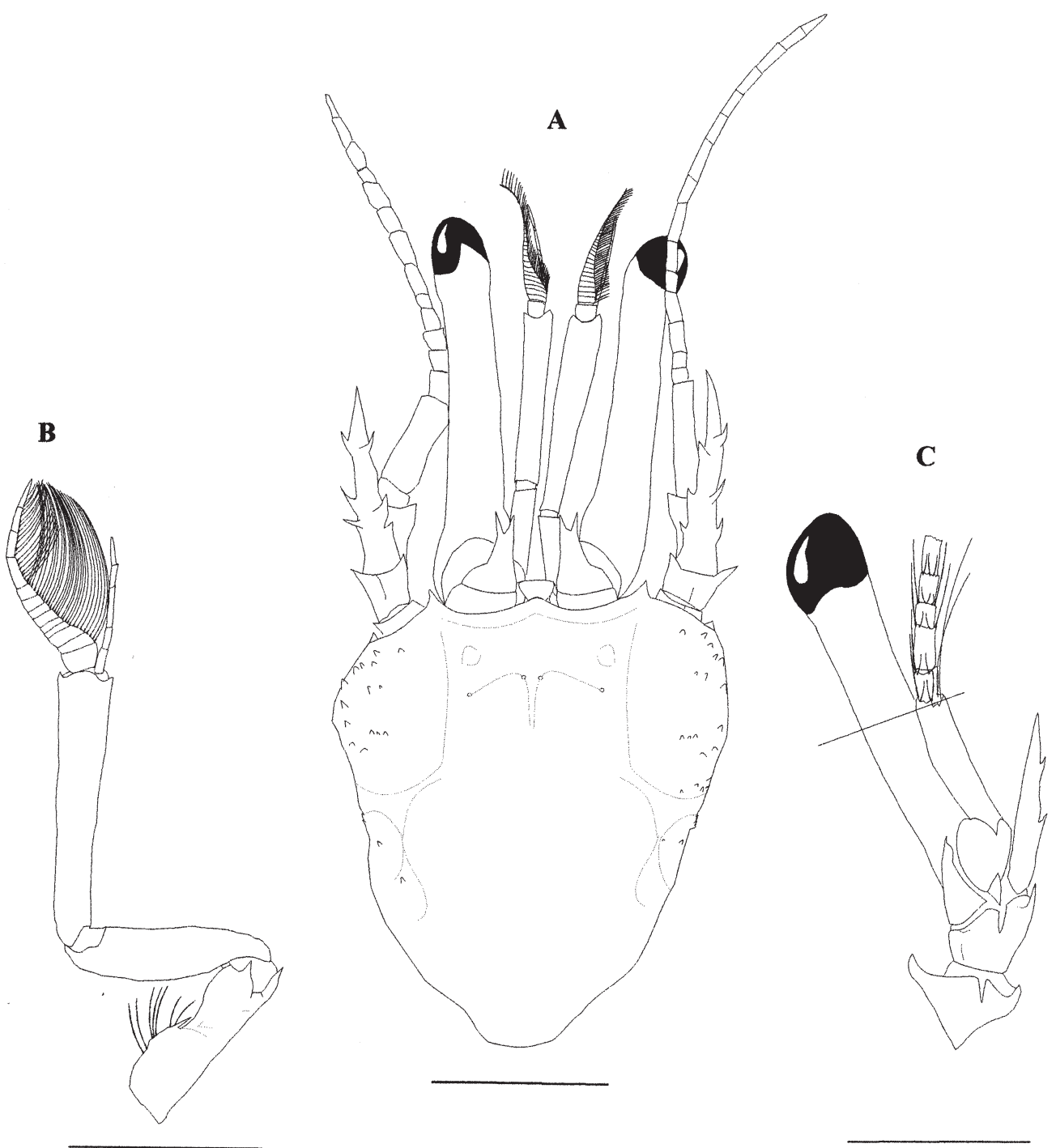

FIG. 2. - Paguristes holguinensis sp. nov. A: shield and cephalic appendices (dorsal view, setae not shown). B: right antennule (lateral view) C: left antenna and ocular peduncle (lateral view). Holotype, ơ (6JA-10). Scales: A, $2 \mathrm{~mm}$; B and C, $1 \mathrm{~mm}$

Provenzano, 1974 b) and (2) the coloration: a redorange coloration in the ocular peduncles and an orange-spotted appearance in the chelipeds and ambulatory legs could be observed in well preserved specimens of $P$. paraguanensis, whereas $P$. erythrops (prone to lose the color before than $P$. paraguanensis) has carmine ocular peduncles and prominent reddish patches on the dorsal surfaces of the palms and carpus of the chelipeds and on the mesial and lateral faces of the propodus, carpus and merus of the ambulatory legs.

\section{Paguristes holguinensis sp. nov.}

Type material: Holotype, Jururú Bay (Provincia de Holguin NE Cuba), shallow waters, 25-04-1998: (6JA-10) 1 ô (SL: $2.68 \mathrm{~mm}$ ). Deposited in Instituto de Oceanología de Cuba. Paratypes, Jururú
Bay (Provincia de Holguin, NE Cuba), shallow waters, 25-04-1998: (10JA-11) 1 đิ (SL: $3.04 \mathrm{~mm}$ ). Vita Bay (Provincia de Holguin, NE Cuba) 2-3 m, 17-04-1988: (2VA-6) 1 9 (SL: $1.99 \mathrm{~mm}$ ); (2VA-9) 10 (SL: $2.01 \mathrm{~mm})$; (2VA-12) 1 क (SL: $2.17 \mathrm{~mm}) ;(2 \mathrm{VA}-15) 10$ (SL: $1.80 \mathrm{~mm})$; (2VA-26) 1 우 $(\mathrm{SL}: 2.00 \mathrm{~mm}) ;(26 \mathrm{VA}-5) 1$ \% (SL: $2.41 \mathrm{~mm}$ ) and 1 o (SL: $2.00 \mathrm{~mm})$. Deposited in the Dept. Biología Animal, Universidad de Málaga.

Etymology: This species is named after the type locality, Holguin.

Description: Shield (Fig. 2A) longer than broad; dorsal surface rugose, with some small spines marginally and laterally, mainly in the anterolateral parts of shield, and sparse short setae. Lateral projections broadly triangular, acute with terminal spinule. Rostrum obtuse, not reaching the level of lateral projections. 
Ocular peduncles (Fig. 2C) slender, much longer than half the length of shield, with long setae on the proximal half of dorsomesial margin, mainly proximally. Ocular acicles large, separated, with strong bifid terminal spines (in one specimen, 2VA-15, they are not bifid), with the lateral and mesial faces of acicles straight and without spines (only in one acicle of one specimen was a small spine found in the middle of the mesial face) and the basal parts are not broadly dilated.

Antennular peduncles (Fig. 2B) when fully extended overreach the distal margins of corneas by approximately $1 / 5$ to nearly the entire length of the ultimate segment. Ultimate and penultimate segments without setae. Basal segment ending in two lobes, each one with a spine in the distal mar- gin, and another in the dorsolateral margin of the statocyst lobe.

Antennal peduncles (Fig. 2C) overreaching the midlength of the ocular peduncle. Fifth segment nude, projected ventrally. Third segment with a strong distal spine. Second segment with two strong spines in the dorsal margin, one mesial and one lateral. Antennal acicle overreaching the half length of the fifth segment, with two or three spines in the dorsolateral and two or three spines in the dorsomesial margins and a terminal one; ventral side nude. Antennal flagellum short, in most cases equal to or longer than carapace; each article with short (one article in length) and long (length variable: two and a half article in length, in most specimens) setae in the distal margin.
A

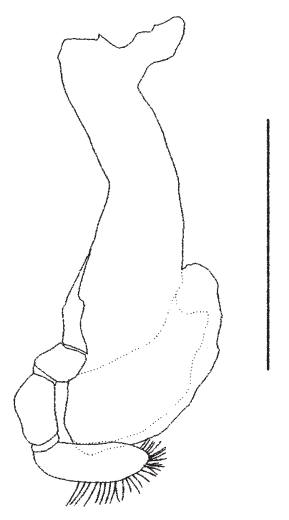

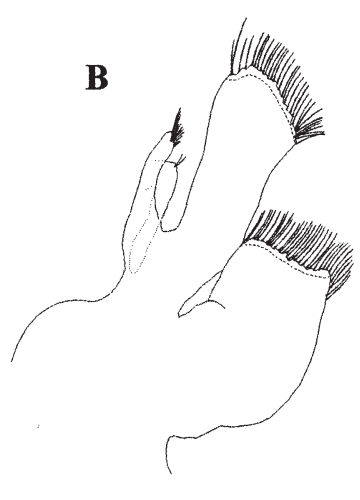
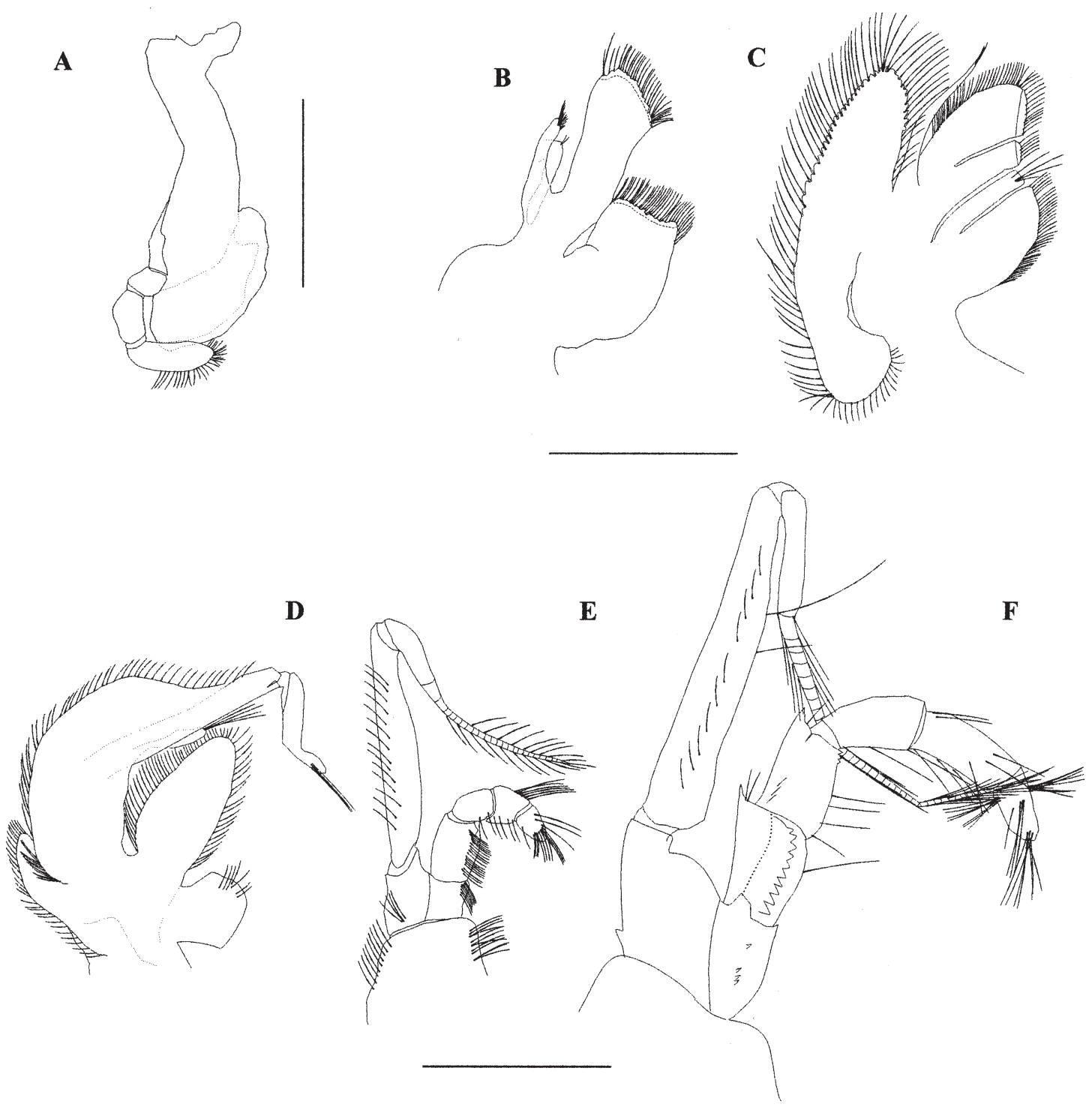

FIG. 3. - Paguristes holguinensis sp. nov. Mouth appendices (mesial view). A: mandible. B: maxillule. C: maxilla. D: first maxilliped. E:

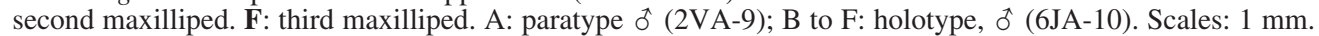



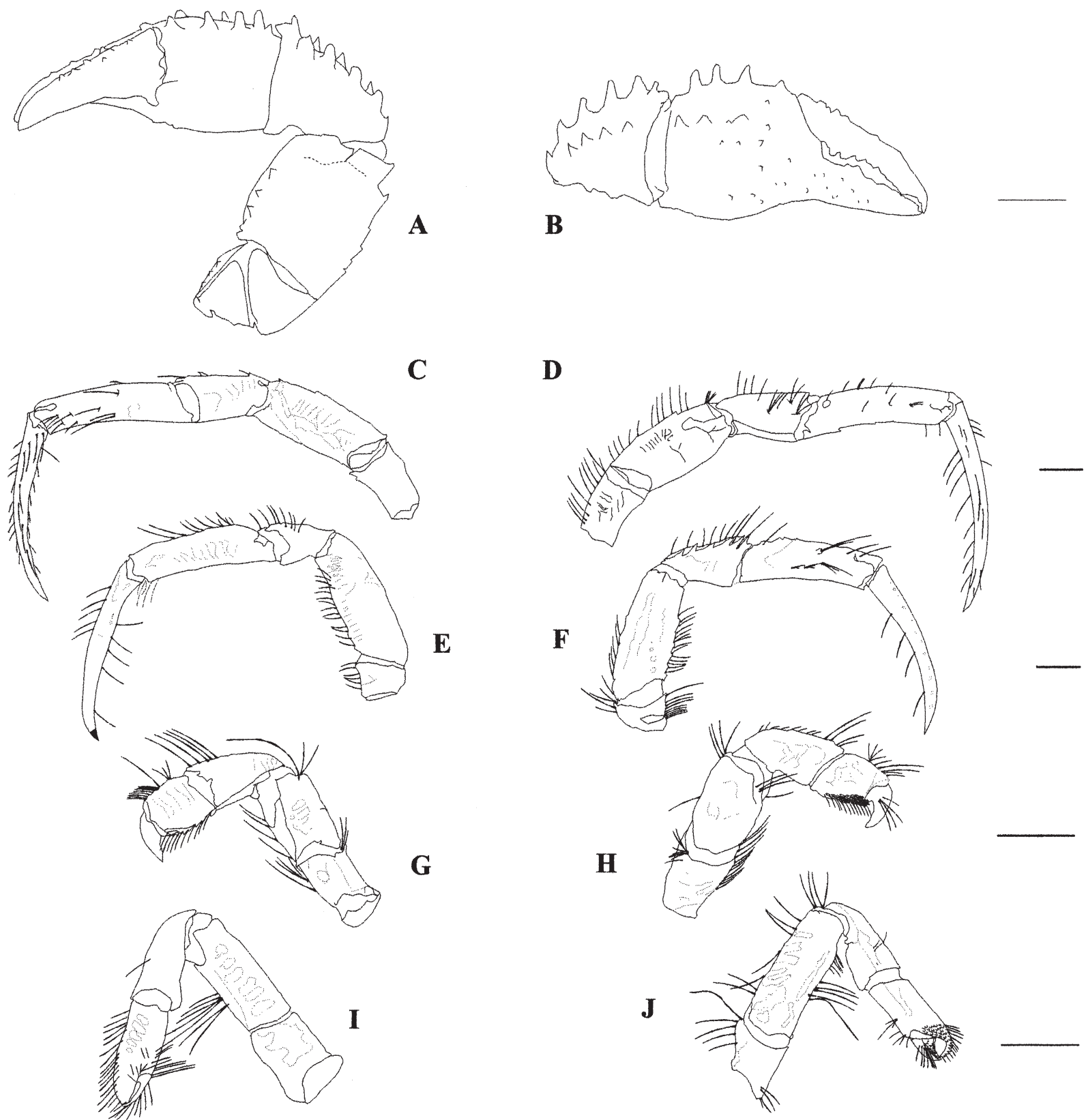

FIG. 4. - Paguristes holguinensis sp. nov. A, B: cheliped (right one A: mesial view, B: dorsal-outer view, setae not shown). C, D: second pereiopod (left one C: lateral view, D: mesial view). E, F: third pereiopod (left one E: lateral view, F: mesial view). G, H: fourth pereiopod (left one G: lateral view, H: mesial view). I, J: fifth pereiopod (left one I: lateral view, J: mesial view). A, B: Holotype, ô (6JA-10); C to J: paratype ờ (2VA-9). Scales: $1 \mathrm{~mm}$.

Mandible (Fig. 3A) with a palp with three segments; first segment smaller than second, and second smaller than the third. Maxillule (Fig. 3B) with internal endite subquadrate; endopodite with several (4-5) setae on the internal lobe, external lobe well developed, curved, more than half the endopodal length. Maxilla (Fig. 3C) with endopodite slightly exceeding scaphognathite in distal extension.

First maxilliped (Fig. 3D) with endopodite short, approximately half the length of exopodite; epipodite moderately well developed, margin with plumose setae.

Second maxilliped (Fig. 3E) without distinctive characters, basis-ischium separated with a suture.

Third maxilliped (Fig. 3F) with basis-ischium distinctive, with a visible suture, although basis is almost broken in the middle; basis with 4 small spines, 3 proximal and one distal; ischium with strong crista dentata well developed with a single row of 12 teeth and with a strong spine in the dor- 
sodistal margin; no accessory tooth; merus with 2 spines on the distal-medial half of the ventral margin and with a strong spine in the dorsodistal margin; carpus, propodus and dactyl nude.

Chelipeds (Fig. 4A, B, setae not shown) subequal; left slightly larger; armature generally similar. Dactyl slightly longer than palm, cutting edge with a row of calcareous teeth proximally, terminating in a corneous claw, dorsal surface with a row of small spinulose tubercles decreasing in size distally and scattered tufts of setae, outer face with tuft of setae and inner face nude. Palm longer than carpus; outer face convex with a dorsal row of 4 or 5 strong spines, with stiff setae, and with a row of 3 or 4 strong spinulose tubercles on the medial part and other smaller ones on the distal part, inner face with 2 ventrodistal tubercles, fixed finger with tuft of setae and some small tubercles (in general, each tubercle is usually accompanied by a tuft of stiff setae). Carpus almost as large as merus; outer face with 2 rows of strong spinulose tubercles: one dorsal with 5 or 6 spines and the other on the medial part with 4 spines, separated by one unarmed longitudinal strip. Merus with one dorsodistal spine and with a row of small spines (variable in number) in the dorsal margin, decreasing in size proximally, accompanied by tufts of moderately long setae; ventromesial and ventrolateral margins each one with a row of small tubercles.

Second pereiopod (Figs. 4C, D) moderately long; dactyl a little longer than the propodus of the cheliped (including the fixed finger) and 1.38 times longer than its propodus, moderately curved and terminating in a corneous-tipped spine; carpus 0.63 times the propodus, with 2 very small dorsal spinules (distally and proximally); merus 0.88 times the propodus length and with very small dorsal spinules (3-4). Third pereiopod (Figs. 4E, F) very similar to the second one; only the dorsal spines on merus and especially the ones of the carpus are more developed (5-6 strong spines in the latter). Ventral surface of the segments of the second and third legs smooth, except in the ventrolateral crest of merus in which some small spines can be found, mainly in the third leg (where sometimes, some tubercles can be observed on the outer face). Fourth (Figs. 4G, H) and fifth (Figs. 4I, J) pereiopods without any special distinctive character.

First and second pleopods of males are paired (Figs. 5A-D) and modified as gonopods. First pleopods (Figs. 5A, B) with basal segment with tuft of long stiff bristles at superior mesial angle; mesial
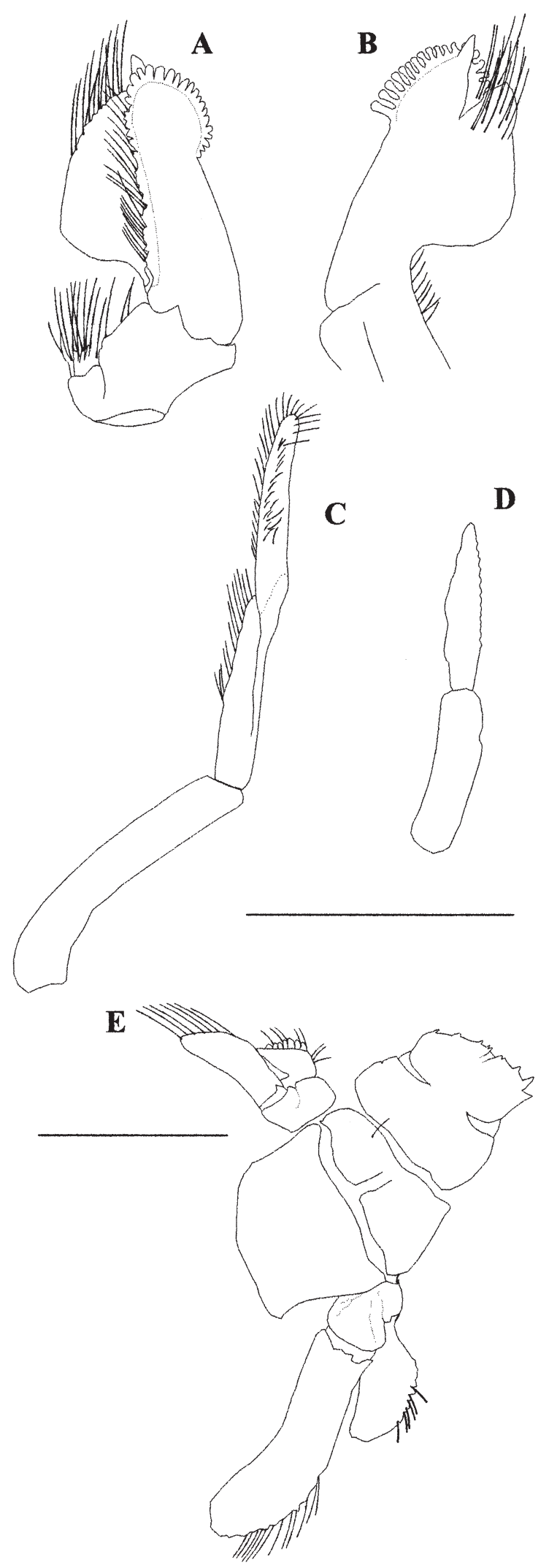

FIG. 5. - Paguristes holguinensis sp. nov. A, B; first left masculine pleopod (A: lateral view, B: mesial view). C: second left pleopod of male (lateral view), D: first left pleopod of female (ventral view). E: telson and uropods (dorsal view). A to C and E: Holotype $\widehat{\delta},(6 \mathrm{JA}-$ 10); D: paratype + (2VA-26). Scales: $0.5 \mathrm{~mm}$. 
margin with row of long fine setae; distal margin of inferior lamella with row of subacute holed spines; external lobe moderately slender slightly overreaching the inferior lamella; internal lobe shorter than external lobe in distal extension and set apart by prominent space, mesial and distal margins and distal third of inferior margin with long bristles and stiff setae. Second pleopods (Fig. 5C) with penultimate segment nude; ultimate segment with relatively long setae and appendix masculina with marginal bands of moderately short bristles. Third to fifth pleopods unpaired, with well developed exopodites.

Female gonopores paired. First pleopods of females paired and modified (Fig. 5D), with basal segment as long as the distal one. Second to fifth pleopods unpaired (only on the left side), second to fourth with both rami well developed with long plumose setae in the whole pleopod, fifth with endopodite rudimentary. There is no brood pouch. Mean diameter of the eggs: $27.8 \mathrm{~mm}$; standard deviation: $\pm 1.48 \mathrm{~mm}$.

Telson (Fig. 5E) with practically symmetrical lobes, the left one very slightly larger than the right one, separated by a narrow median cleft delimited by two (sometimes three or four) spines in both margins. Terminal margins of left lobe with five to eight spines of small-medium size, the lateral are stronger; right lobe with a similar structure.

Coloration: Ocular peduncle iridescent (the proximal half of the peduncles show a dorsal white band in alcohol-preserved specimens). The antennular peduncles show a longitudinal red-iridescent band in the last article. Shield with red-iridescent patches.

Distribution: The specimens have only been found in the superficial coral reef between 2 and 3 $\mathrm{m}$, in Vita Bay and Jururú Bay, province of Hologuín, NE of Cuba (Fig. 1).

Affinities: P. holguinensis is very easy to differentiate from the other species of Paguristes of the Caribbean Sea, with obtuse rostrum not reaching the level of the lateral projections, because of its separated ocular acicles having a strong bifid terminal spine. Only Paguristes planatus A. Milne Edwards and Bouvier, 1893, among the Caribbean species, presents both these characters. The most reliable characters for separating them are: a) the antennular peduncle length, which is longer in $P$. holguinensis than in P. planatus (in this species it only reaches the distal part of the cornea); b) the antennal acicle, which is more spinous in $P$. planatus; c) the absence of brood pouch in the females of $P$. holguinensis which carry the eggs directly on their pleopods and d) the thoracic sternum, which is very broad in $P$. planatus.

\section{ACKNOWLEDGEMENTS}

We wish to acknowledge, with thanks, the assistance of Dr. P.A. McLaughlin from Shannon Point Marine Center, Western Washington University, and Dr. Rafael Lemaitre from the Smithsonian Institution for helping with the references and suggestions. Also, we wish to express our most sincere appreciations to Dr. Nancy Voss and Dr. Julio García Gómez, from Rosenstiel School for Marine and Atmospheric Science, University of Miami, for their inestimable help and for authorising the study of the Pagurids collections. Thanks also to the short-term visitor grant of the University of Málaga. Also, our gratitude goes to Dr. Ardis B. Johnston and Dr. Gonzalo Giribet of the Museum of Comparive Zoology (Harvard University), for the loan of specimens (Paguristes planatus: the holotype (MCZ 4032), Paguristes sericeus: 1 lectotype (MCZ 3987), 2 paralectotype (MCZ 6333, MCZ 3983) and 1 nontype (MCZ3986)) for comparative purposes.

This study was carried out under the auspices of the Spanish "Ministerio de Educación y Ciencia, Secretaría General Técnica, Subdirección General de Cooperación Internacional", within the Iberoamerica Cooperation Programme, Project: "Biodiversidad y estructura de las comunidades de los crustáceos decápodos paguroideos en los diferentes biotopos marinos litorales de Cuba".

\section{REFERENCES}

Benedict, J.E. - 1901. The anomuran collections made by the Fish Hawk Expedition to Porto Rico. Bull. U..S. Fish Comm., 20: 129-148.

Boone, L. - 1930. Crustácea: Anomura, Macrura, Schizopoda, Isopoda, Amphipoda,Mysidacea, Cirripedia and Copedpoda. Scientific Results of the Cruises of the Yachts "Eagle" and “Ara”, 1921-1928, William K. Vanderbilt, Commanding. Bull. Vanderbilt Mar. Mus. 3: 21-50.

Bouvier, E.L. - 1918. Sur une petite collection de Crustacés de Cuba offerte au Museum par M. Boury. Bull Mus. natn. Hist. nat., 24: 6-15

Campos C.N.H. and H. Sánchez M. - 1995. Los cangrejos ermitaños del género Paguristes Dana (Anomura: Diogenidae) de la costa norte colombiana, con la descripción de dos nuevas especies. Caldasio, 17(82-85): 569-585.

Chace, F.A. - 1939. Reports on the Scientific Results of the first Atlantis Expedition to the West Indies, under the joint auspices 
of the University of Havana and Harvard University. Mem. Soc. Cubana Hist. Nat., 18(1): 31-51.

Dana, J.D. - 1852. On the classifications of the Corystoidea, Paguridae, etc. Am. J. Sci. and Arts, ser. 2, 13(37): 119-124.

Forest, J. - 1954. Sur un Pagure Littoral Noveau de la Martinique, Paguristes cadenati sp. nov. Bull Mus. natn. Hist. nat., 3 (26): 353-357.

Forest, J. and M. de Saint Laurent. - 1967. Résultats scientifiques des campagnes de la Calypso. Campagne de la "Calypso au large des côtes Atlantiques de l'Amérique du Sud (1961-1962). 6. Crustacés Décapodes: Pagurides. Annls. Inst. océanogr. Monaco, 45(2): 47-169."

Gómez Hernández, O. and J.C. Martínez-Iglesias. - 1986. Nueva lista de pagúridos cubanos (Crustacea, Decapoda, Anomura, Paguroidea). Rev. Invest. Mar., Univ. Habana, 7 (2):21-29.

Gómez Hernández, O. and C. Pérez P. - 1984. Lista de los pagúridos cubanos (Crustacea, Decapoda, Anomura). Rev. Invest. Mar., Univ. Habana, 51(1):23-34

Gómez Hernández, O. and C. Pérez P. - 1987. Algunas consideraciones ecológicas sobre pagúridos cubanos. Rev. Invest. Mar. Univ. Habana, 8 (1): 15-39.

Guérin-Meneville, F.E. - 1856. Crustáceos. In Sagra, R.: Historia Física Política y Natural de la Isla de Cuba, 7.

Gundlach J. and J. Torralbas. - 1896. Contribución al estudio de los Crustáceos de Cuba. Anales Acad. Cienc. Méd. Fís. y Nat. Habana.

Holthuis, L.B. - 1959. The Crustacea Decapoda of Suriname (Dutch Guiana). Zool. Verhandl. Leiden, 44: 1-296.

Lalana, R., M. Ortiz and O. Gómez Hernández. - 1980. Lista de invertebrados bentónicos de las lagunas costeras "Tolete" y "El Basto" de la zona de Tunas de Zaza. Rev. Invest. Mar. Univ. Habana, 1: 36-37.

MacLaughlin, P.A. and A.J. Provenzano. - 1974a. Hermit crabs of the genus Paguristes (Crustacea: Decapoda: Diogenidae) from the Western Atlantic. Part I. The Paguristes tortugae complex with notes on variation. Bull. Mar. Sci., 24 (1): 165-234.

MacLaughlin, P.A. and A.J. Provenzano. - 1974b. Hermit crabs of the genus Paguristes (Crustacea: Decapoda: Diogenidae) from the Western Atlantic. Part II. Descriptions of six new species. Bull. Mar. Sci., 24 (4): 165-234.

Martens, E. von. - 1872. Ubre Cubanische Crustaceen nach den Samulungen Dr. J. Gundlach's Arch. F. Naturgesch, 38 (1) 117-122.

Martínez-Iglesias, J.C. and J.E. García Raso. - 1999. The crustacean decapod communities of tree coral reef from the southwestern Caribbean Sea of Cuba: species composition, abundance and structure of the communities. Bull. Mar. Sci., 65(2): 539-557.

Martínez-Iglesias, J.C. and O. Gómez Hernández. - 1989. Una especie nueva del género Paguristes (Crustacea: Decapoda: Diogenidae) en aguas de Cuba. Poeyana, 379: 1-30.

Martínez-Iglesias, J.C:, O. Gómez Hernández, A. Carvacho and R. Ríos. - 1993. Nuevos registros de crustáceos decápodos (Crustacea: Decapoda) en la plataforma marina de Cuba. Avicenia, 0: 9-13.

Milne Edwards, A. - 1880. Report on the results of dredging in the Gulf of Mexico and in the Caribbean Sea, 1877, '78, '79, by the U.S. Coast Survey Steamer "Blake". VIII. Études préliminaires sur les crustacés. Bull. Mus. Comp. Zool., Harvard Coll., 8(1): 1-68.

Milne Edwards, A. and E. L. Bouvier. - 1893. Report on the results of dredging in the Gulf of Mexico (1877-78) and in the
Caribbean Sea (1878-79), and along the Atlantic coast of t.he United States (1880). XXXIII. Description Des Crustacés de la famille des Paguriens recueillis pendant l'Expédition. Bull. Mus. Comp. Zool., Harvard Coll., 14(3):1-172.

Ortiz, M. - 1976. Algunas características del Bentos de Cuba. Ciencias. Rev. Invest. Mar., Univ. Habana, 22 (8): 1-32.

Ortiz, M and O. Gómez-Hernández. - 1986. Una nueva especie del género Pylocheles (Anomura: Galatheoidea) de las aguas profundas del Sur de Cuba. Rev. Invest. Mar., Univ. Habana, 7(1: 31-37.

Parra, A. - 1787. Descripción de diferentes piezas de historia natural, la más del ramo marítimo, representadas en setenta y cinco láminas. Impr. de la Capitanía General, Habana Cuba: 170-173.

Provenzano, A. - 1959. The shallow-water hermit crabs of Florida. Bull. Mar. Sci. Gulf and Caribb., 9(4): 349-420.

Provenzano, A. and A.L. Rice. - 1966. Juvenile morphology and the development of taxonomic characters in Paguristes sericeus A. Milne Edwards (Decapoda, Diogenidae). Custaceana, 10(1): 53-69.

Provenzano, A. - 1960. Notes on Bermuda Hermit Crabs (Crustácea: Anomura). Bull. Mar. Sci. Gulf and Caribb., 10(1): 117-124.

Provenzano, A. - 1962. Pagurid crabs (Decapoda Anomura) from Dt. John, Virgin Islands, with descriptions of three new species. Crustaceana, 3(2): 151-166.

Provenzano, A. - 1965. Two new West Indian hermit crabs of the genus Paguristes (Crustacea Dogenidae). Bull. Mar. Sci., 15(3): 726-736.

Rodríguez, G. - 1980. Los crustáceos Decápodos de Venezuela. Inst. Venezolano de Invest. Cient.: 209-234.

Sandberg, L. - 1996. Hermit crabs of the genus Paguristes (Crustacea: Decapoda) from the western Atlantic Part III. Paguristes markhami, a new species from de Bahamas and Caicos Islands. Proc. Biol. Soc. Washington, 109(3): 470-475.

Schmitt, W.L. - 1933. Four new species of decapod crustaceans from Porto Rico. Am. Mus. Novit., 662: 1-9.

Schmitt, W.L. - 1935. Crustacea Macrura and Anomura for Porto Rico and the Virgin Islands. Sci. Surv. Porto Rico and Virgin Islands, New York Acad. Sci., 15(2): 198-208.

Stimpson, W. - 1859. Notes on North American Crustaceans. Ann. Lyceum. Nat. Hist. New York, 7: 49-93.

Torralbas, F. - 1917. Contribución al estudio de los Crustáceos de Cuba. Notas del Dr. Juan Gundlach copiadas y completadas por el Dr. José Torralbas y publicadas por el Dr Federico Torralbas. An. Acad. Cienc. Méd., Fís. y Nat. Habana. LIII-36: 543-624.

Valdés, P. - 1909. Clasificación Gundlach de Crustáceos cubanos conforme a los ejemplares existentes en el Museo Cubano del Instituto de la Habana, 45: 623-624.

Wass, M.L. - 1955. The decapod crustaceans of Alligator Harbor and adjacent inshore areas of northwestern Florida. Quart. J. Florida. Acad. Sci., 18(3): 129-176.

Wass, M.L. - 1963. New species of hermit crabs (Decapoda, Paguridae) from the western Atlantic. Crustaceana, 6(2): 133157.

Williams, A.B. - 1965. Marine decapod crustaceans of the Carolinas. Fish. Bull. 65(1): 1-298.

Williams, A.B. - 1984. Shrimps, lobsters and crabs of the Atlantic coast of the eastern United States, Maine to Florida. Smithsonian Institution Press. Washington D.C., 1- 550.

Scient. ed.: P. Abelló 